\title{
The Influence of Atmospheric Parameters on Production and Distribution of Air Pollutants in Bayelsa: A State in the Niger Delta Region of Nigeria
}

\author{
E. I. Njoku*, O. E. Ogunsola, E. O. Oladiran \\ Department of Physics, University of Ibadan, Ibadan, Nigeria \\ Email: *emmanuelnjoku123@gmail.com
}

How to cite this paper: Njoku, E.I., Ogunsola, O.E. and Oladiran, E.O. (2019) The Influence of Atmospheric Parameters on Production and Distribution of Air Pollutants in Bayelsa: A State in the Niger Delta Region of Nigeria. Atmospheric and Climate Sciences, 9, 159-171.

https://doi.org/10.4236/acs.2019.91011

Received: December 1, 2018

Accepted: January 14, 2019

Published: January 17, 2019

Copyright $\odot 2019$ by author(s) and Scientific Research Publishing Inc. This work is licensed under the Creative Commons Attribution International License (CC BY 4.0). http://creativecommons.org/licenses/by/4.0/

\section{Open Access}

\begin{abstract}
Air pollution is a primary environmental problem in the Niger Delta region of Nigeria due to oil spills including the gas emissions associated with industrial effluents. However, a good understanding and quantification of atmospheric parameters (wind speed, wind direction, temperature, relative humidity, solar radiation and cloud cover) that influence air pollution $\left(\mathrm{CH}_{4}, \mathrm{NO}_{2}\right.$ and $\mathrm{O}_{3}$ ) concentrations in this region could assist in the mitigation and distribution of these pollutants. This work examines the influence of atmospheric parameters on the production and distribution of air pollutants in the Niger Delta region of Nigeria for the development of control strategies that will enhance the mitigation and amelioration of the significant impacts that these atmospheric pollutants could have on the populace in this part of the country. The $\mathrm{CH}_{4}$ and $\mathrm{NO}_{2}$ data utilized in this study were sourced from the European Space Agency (ESA), while that of tropospheric ozone $\left(\mathrm{O}_{3}\right)$ was obtained from the National Aeronautics and Space Administration (NASA), and the atmospheric parameters data were provided by the Nigeria Meteorological Agencies (NIMET), Lagos. The analysis of the daily pollutants $\left(\mathrm{CH}_{4}\right.$, $\mathrm{NO}_{2}$ and $\mathrm{O}_{3}$ ) including the atmospheric parameters in this region of the Niger Delta for the period 2003 to 2010 was carried out using standard statistical approach including the graphical method, stepwise regression model, least-square method, and correlation analysis. The Mann-Kendal rank statistics was also utilized in identifying the meaningful long-term trends, validation and testing of the homogeneity of the concentrations of the pollutants. The results of the correlations of $\mathrm{CH}_{4}, \mathrm{NO}_{2}$ and $\mathrm{O}_{3}$ concentrations with their previous day's concentrations showed a strong significance in regression analysis for both $\mathrm{CH}_{4}$ and $\mathrm{O}_{3}$. The coefficient of determination of $\mathrm{CH}_{4}$ and $\mathrm{O}_{3}$ was obtained as
\end{abstract}


0.654 and 0.810 respectively, while a very weak correlation was obtained for $\mathrm{NO}_{2}$. However, despite that a very strong negative correlation of -0.809 and -0.900 was obtained between wind speed and both the $\mathrm{CH}_{4}$ and $\mathrm{O}_{3}$ pollutants respectively, a moderate correlation was obtained between the wind speed and $\mathrm{NO}_{2}$. This implies that amongst the atmospheric parameters considered in this study for the region of the Niger Delta in Nigeria, wind speed has much influence on the variation of both $\mathrm{CH}_{4}$ and $\mathrm{O}_{3}$ concentrations, but with a little influence on the $\mathrm{NO}_{2}$ concentrations.

\section{Keywords}

Air Pollution, Atmospheric Parameters, Atmospheric Pollutants, Regression Analysis, Correlations

\section{Introduction}

Air pollution is the emission of chemical effluents from numerous sources into the atmosphere which could cause harm to both man and plants including damage to life and property. These pollutants are of many forms including ozone $\left(\mathrm{O}_{3}\right)$, carbon monoxide $(\mathrm{CO})$, sulphur dioxide $\left(\mathrm{SO}_{2}\right)$, nitrogen oxides $\left(\mathrm{NO}_{\mathrm{x}}\right)$, hydrogen sulphide $\left(\mathrm{H}_{2} \mathrm{~S}\right)$, hydrogen fluoride $(\mathrm{HF})$ and volatile organic compounds (VOC) [1]. Also, the chemical effluents being referred to as pollutants are been influenced by so many factors including wind speed, temperature and humidity. The wind speed influences the quantity of the pollutants to be dispersed, while temperature assists in transforming the pollutants to other forms [2].

The discovery of oil has been causing series of negative environmental effects in the Niger Delta region, where all the petroleum exploration and production has been taking place in Nigeria [3] [4]. In this region, gas flaring which is thought to be very important in the elimination of gas, especially when the volume is thought to be economically insufficient to warrant recovery or collection is on the increase in recent years, thereby causing many health hazards both to people and to animals [5]. The increasing effect of the rapid population growth in the Niger Delta region, including the industrialization, and increased use of vehicles has also made the situation in this region to become worse. Moreover, the Niger Delta has been witnessing water and land contamination with consequent degradation of the agricultural land with the effective enforcement of regulatory measures yielding no measurable results. Activities related to petroleum exploration, development and production operations have local disadvantages and effects on the atmosphere, soils and sediments, surfaces and groundwater, marine environment, biologically diversity and sustainability of terrestrial ecosystems in the Niger Delta [6]. Furthermore, [4] carried out systematic studies of the air quality of the Niger Delta region and found out that carbon monoxide, nitrogen dioxide, sulphur dioxide and carbon dioxide effluents vary in the Niger 
Delta. Also, [7] carried out the analysis of carbon monoxide concentrations with some selected meteorological variables such as temperature, relative humidity and wind speed in ten major urban centres in the south eastern part of Nigeria. The correlation analysis reveals that among the meteorological parameters studied; only wind speed is strongly correlated with carbon monoxide in the south eastern Nigeria. However, there are other sources of pollution in Nigeria which include those from vehicular sources [8] [9] [10] [11].

This work is focused on the Bayelsa state of Nigeria (Figure 1) which is one of the nine states in the Niger Delta region, due to its been exposed to much environmental degradation and health hazards as a result of oil spills and gas emissions associated with the industrial effluents in this area.

\section{Materials and Methods}

The $\mathrm{CH}_{4}$ and $\mathrm{NO}_{2}$ data utilized in this study were sourced from the European Space Agency (ESA), while that of tropospheric ozone $\left(\mathrm{O}_{3}\right)$ was obtained from the National Aeronautics and Space Administration (NASA), and the atmospheric parameters data were provided by the Nigeria Meteorological Agencies (NIMET), Lagos.

The $\mathrm{CH}_{4}$ and $\mathrm{NO}_{2}$ data utilized in this study were sourced from the European Space Agency (ESA), while that of tropospheric ozone $\left(\mathrm{O}_{3}\right)$ was obtained from the National Aeronautics and Space Administration (NASA), and the atmospheric parameters data were provided by the Nigeria Meteorological Agencies (NIMET), Lagos. The analysis of the daily pollutants $\left(\mathrm{CH}_{4}, \mathrm{NO}_{2}\right.$ and $\left.\mathrm{O}_{3}\right)$ including the atmospheric parameters in this region of the Niger Delta for the period 2003 to 2010 were carried out using standard statistical approach including the graphical method, stepwise regression model, least-square method, and correlation analysis. The Mann-Kendal rank statistics was also utilized in identifying the meaningful long-term trends, validation and testing of the homogeneity of the concentrations of the pollutants.

\section{Results and Discussion}

The result of the regression statistics showed that wind speed has a greater negative influence on the concentration of $\mathrm{CH}_{4}$ and Ozone $\left(\mathrm{O}_{3}\right)$ respectively. The decrease in the wind speed increases the concentration of the pollutants for they tends to accumulate near the source point but the decrease in the wind speed decreases the concentrations of these pollutants as much pollutants will be dispersed by wind. The measured and the predicted values of these pollutants $\left(\mathrm{CH}_{4}\right.$ and $\mathrm{O}_{3}$ ) as observed from the regression equation were presented in Table 1.

The result of the correlation analysis showed that only wind speed among all the meteorological parameters considered has the strongest negative influence on these pollutants with the value $81 \%$ and $91 \%$ for $\mathrm{CH} 4$ and $\mathrm{O}_{3}$ respectively (Table 2). Tables 3-7 which showed the minimum and the maximum annual trends values of the pollutants within the period considered was utilized in 


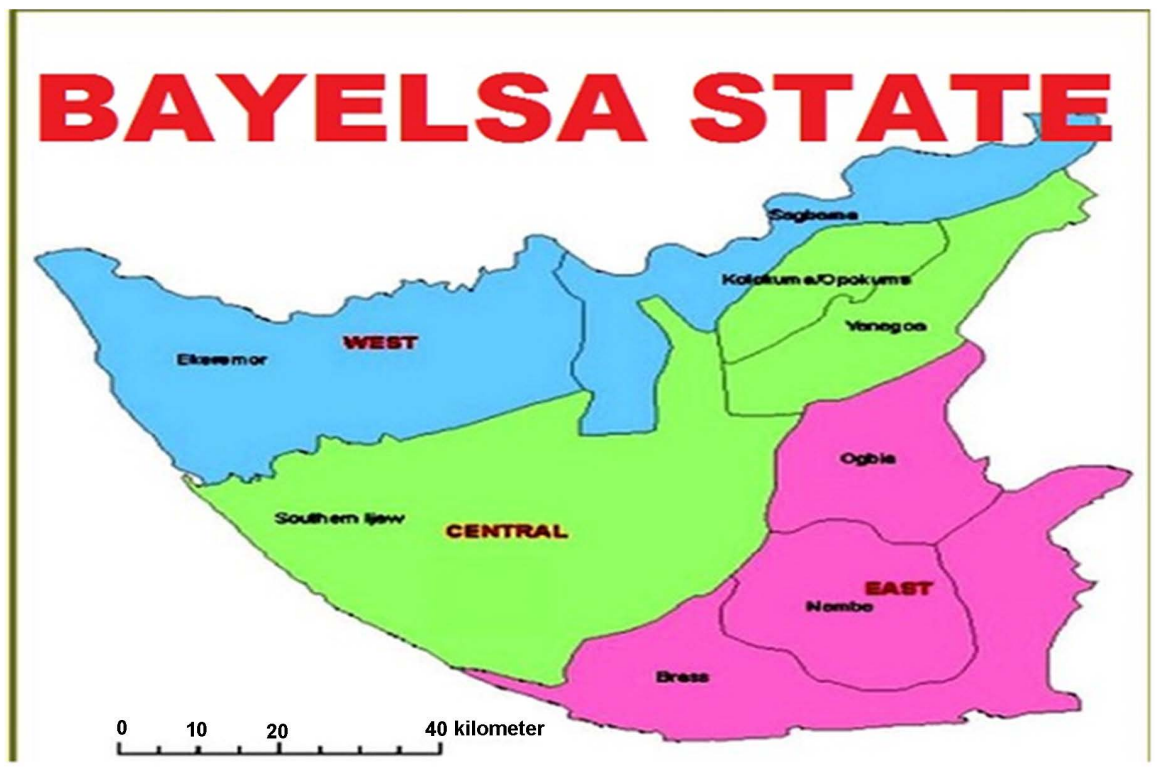

Figure 1. Map of Bayelsa State showing the study area (Apoi Creek) Southern Ijaw, sourced from NARSDA.

Table 1. The measured and the predicted values of $\mathrm{CH}_{4}$ and $\mathrm{O}_{3}$.

\begin{tabular}{ccccccc}
\hline Years & $\begin{array}{c}\mathrm{CH}_{4} \\
\text { (measured) }\end{array}$ & Wind Speed & $\begin{array}{c}\mathrm{CH}_{4} \\
\text { (predicted) }\end{array}$ & $\begin{array}{c}\mathrm{O}_{3} \\
\text { (measured) }\end{array}$ & Wind Speed & $\begin{array}{c}\mathrm{O}_{3} \\
\text { (predicted) }\end{array}$ \\
\hline 2003 & 1733.685 & 4.828965 & 1735.945 & 0.005655 & 4.828965 & 0.005657 \\
2004 & 1729.42 & 6.687811 & 1728.642 & 0.005602 & 6.687811 & 0.005525 \\
2005 & 1729.149 & 6.676661 & 1728.685 & 0.005479 & 6.676661 & 0.005526 \\
2006 & 1722.8 & 6.471819 & 1729.49 & 0.005629 & 6.471819 & 0.00554 \\
2007 & 1734.205 & 6.729039 & 1728.48 & 0.005566 & 6.729039 & 0.005522 \\
2008 & 1736.168 & 4.23183 & 1738.291 & 0.005741 & 4.23183 & 0.005699 \\
2009 & 1741.963 & 4.02259 & 1739.113 & 0.005784 & 4.02259 & 0.005714 \\
2010 & 1740.801 & 3.91419 & 1739.539 & 0.005746 & 3.91419 & 0.005722 \\
\hline
\end{tabular}

Table 2. Pearson correlation of some meteorological parameters against the pollutant concentrations.

\begin{tabular}{cccccccc}
\hline & SR & RH & WNDSPD & WNDDR & CC & TMIN & TMAX \\
\hline $\begin{array}{c}\text { Methane Pearson } \\
\text { Correlation }\end{array}$ & -0.357 & 0.236 & $-0.809^{*}$ & -0.332 & 0.118 & -0.219 & -0.329 \\
$\mathrm{NO}_{2}$ Pearson Correlation & -0.412 & 0.396 & 0.213 & 0.568 & 0.375 & 0.337 & 0.181 \\
$\begin{array}{c}\text { OZONE Pearson } \\
\text { Correlation }\end{array}$ & -0.310 & 0.364 & $-0.900^{* *}$ & -0.445 & 0.018 & -0.288 & 0.059 \\
\hline
\end{tabular}

$\mathrm{SR}=$ Solar Radiation, $\mathrm{RH}=$ Relative Humidity, $\mathrm{WNDSPD}=$ Wind Speed, $\mathrm{WNDDR}=$ Wind direction, $\mathrm{CC}$ $=$ Cloud Cover, $\mathrm{TMIN}=$ Minimum Temperature, $\mathrm{TMAX}=$ Maximum Temperature.

deducing the spatial interpretations of the pollutants' concentrations in Niger Delta while Table 8 and Table 9 shows the Man-Kendal rank statistical table within the period of studies. The regression analysis between the measured and predicted $\mathrm{CH}_{4}$ (Figure 2) has a relationship expressed as: 
Table 3. Basic statistics of monthly averages of air pollutant concentrations and their maximum and minimum values within the period of investigation Methane.

\begin{tabular}{cccccc}
\hline Year & Mean & $\begin{array}{c}\text { Standard } \\
\text { deviation }\end{array}$ & Variance & Minimum & Maximum \\
\hline 2003 & 1733.686 & 21.807 & 475.546 & 1701.84 & 1775.74 \\
2004 & 1729.420 & 13.769 & 189.583 & 1704.10 & 1747.80 \\
2005 & 1729.149 & 8.200 & 67.243 & 1718.19 & 1741.13 \\
2006 & 1722.800 & 14.219 & 202.175 & 1705.71 & 1754.33 \\
2007 & 1732.205 & 15.786 & 249.204 & 1709.77 & 1758.43 \\
2008 & 1736.168 & 14.241 & 202.814 & 1703.48 & 1754.65 \\
2009 & 1741.963 & 11.775 & 138.641 & 1723.35 & 1764.90 \\
2010 & 1740.801 & 7.691 & 59.146 & 1728.65 & 1756.84 \\
2011 & 1755.575 & 22.918 & 525.236 & 1722.90 & 1793.17 \\
2012 & 1763.733 & 14.424 & 202.045 & 1740.48 & 1785.71 \\
\hline
\end{tabular}

Table 4. Basic statistics of monthly averages of air pollutant concentrations and their maximum and minimum values within the period of investigation $\mathrm{NO}_{2}$.

\begin{tabular}{ccccc}
\hline Year & $\begin{array}{c}\text { Mean } \\
\left(\times 10^{-5}\right)\end{array}$ & $\begin{array}{c}\text { Standard deviation } \\
\left(\times 10^{-6}\right)\end{array}$ & $\begin{array}{c}\text { Minimum } \\
\left(\times 10^{-5}\right)\end{array}$ & $\begin{array}{c}\text { Maximum } \\
\left(\times 10^{-5}\right)\end{array}$ \\
\hline 2003 & 5.246 & 3.141 & 4.9 & 6.0 \\
2004 & 4.637 & 4.542 & 4.0 & 5.3 \\
2005 & 4.307 & 4.860 & 3.9 & 5.7 \\
2006 & 4.092 & 3.555 & 3.6 & 4.6 \\
2007 & 3.771 & 2.708 & 3.5 & 4.4 \\
2008 & 3.834 & 2.110 & 3.5 & 4.1 \\
2009 & 3.752 & 1.554 & 3.6 & 4.0 \\
2010 & 3.849 & 1.969 & 3.4 & 4.2 \\
2011 & 3.943 & 1.611 & 3.7 & 4.2 \\
2012 & 3.982 & 2.056 & 3.7 & 4.3 \\
\hline
\end{tabular}

Table 5. Basic statistics of monthly averages of air pollutant concentrations and their maximum and minimum values within the period of investigation ozone.

\begin{tabular}{ccccc}
\hline Year & $\begin{array}{c}\text { Mean } \\
\left(\times 10^{-3}\right)\end{array}$ & $\begin{array}{c}\text { Standard deviation } \\
\left(\times 10^{-4}\right)\end{array}$ & $\begin{array}{c}\text { Minimum } \\
\left(\times 10^{-3}\right)\end{array}$ & $\begin{array}{c}\text { Maximum } \\
\left(\times 10^{-3}\right)\end{array}$ \\
\hline 2003 & 5.655 & 3.006 & 5.243 & 6.109 \\
2004 & 5.602 & 2.367 & 5.289 & 5.944 \\
2005 & 5.479 & 1.948 & 5.091 & 5.732 \\
2006 & 5.630 & 3.389 & 5.098 & 6.012 \\
2007 & 5.566 & 2.004 & 5.251 & 5.792 \\
2008 & 5.741 & 3.580 & 5.228 & 6.174 \\
2009 & 5.784 & 2.742 & 5.360 & 6.132 \\
2010 & 5.746 & 2.934 & 5.316 & 6.138 \\
2011 & 5.789 & 2.224 & 5.434 & 6.078 \\
2012 & 5.689 & 3.037 & 5.238 & 6.073 \\
\hline
\end{tabular}


Table 6. Basic statistics of monthly averages of air pollutant concentrations and their maximum and minimum values within the period of investigation $\mathrm{CO}_{2}$.

\begin{tabular}{cccccc}
\hline Year & Mean & Standard deviation & Variance & Minimum & Maximum \\
\hline 2009 & 387.149 & 28.710 & 824.269 & 372.948 & 477.398 \\
2010 & 381.162 & 4.386 & 19.239 & 372.887 & 387.056 \\
2011 & 382.833 & 4.778 & 22.826 & 372.579 & 388.765 \\
2012 & 386.839 & 4.639 & 21.524 & 380.198 & 398.513 \\
2013 & 388.241 & 4.004 & 16.035 & 382.363 & 393.243 \\
\hline
\end{tabular}

Table 7. Basic statistics of annual averages of air pollutant concentrations and their maximum and minimum values within the period of investigation.

\begin{tabular}{cccccc}
\hline Pollutants & Mean & Standard deviation & Variance & Minimum & Maximum \\
\hline Methane & 1738.7500 & 12.50933 & 156.483 & 1722.80 & 1763.73 \\
$\mathrm{NO}_{2}$ & $4.139 \times 10^{-5}$ & $4.771 \times 10^{-6}$ & - & $3.8 \times 10^{-5}$ & $5.2 \times 10^{-5}$ \\
Ozone & $5.668 \times 10^{-2}$ & $1.01 \times 10^{-4}$ & - & $5.4790 \times 10^{-2}$ & $5.7887 \times 10^{-2}$ \\
$\mathrm{CO}_{2}$ & 385.245 & 3.0675 & 9.409 & 381.1618 & 388.2413 \\
\hline
\end{tabular}

Table 8. Man-Kendall rank statistical table for various pollutants.

\begin{tabular}{cccccccccc}
\hline YEARS & $\mathrm{CH}_{4}$ & $\mathrm{U}\left(\mathrm{t}_{\mathrm{i}}\right)$ & $\mathrm{U}^{\prime}\left(\mathrm{t}_{\mathrm{i}}\right)$ & $\mathrm{NO}_{2}$ & $\mathrm{U}\left(\mathrm{t}_{\mathrm{i}}\right)$ & $\mathrm{U}^{\prime}\left(\mathrm{t}_{\mathrm{i}}\right)$ & $\mathrm{OZONE}$ & $\mathrm{U}\left(\mathrm{t}_{\mathrm{i}}\right)$ & $\mathrm{U}^{\prime}\left(\mathrm{t}_{\mathrm{i}}\right)$ \\
\hline 2003 & 1733.685 & 0.154 & -0.77 & $5.25 \mathrm{E}-06$ & 3.696 & -1.848 & 0.005655 & 4.466 & -2.618 \\
2004 & 1729.42 & 1.848 & -0.62 & $4.64 \mathrm{E}-06$ & 2.464 & -0.195 & 0.005602 & 2.926 & -2.464 \\
2005 & 1729.149 & 0.154 & -0.62 & $4.31 \mathrm{E}-06$ & 1.386 & -1.694 & 0.005479 & 5.389 & -3.542 \\
2006 & 1722.8 & 2.002 & -0.154 & $4.09 \mathrm{E}-06$ & 3.079 & -1.232 & 0.005629 & 2.772 & -2.772 \\
2007 & 1734.205 & 1.539 & 0.308 & $3.77 \mathrm{E}-06$ & 0.769 & -0.769 & 0.005566 & 4.004 & -2.156 \\
2008 & 1736.168 & 0 & -1.694 & $3.83 \mathrm{E}-06$ & 2.926 & -1.078 & 0.005741 & 4.158 & -2.772 \\
2009 & 1741.963 & 3.079 & -1.232 & $3.75 \mathrm{E}-06$ & 2.156 & -0.616 & 0.005784 & 4.928 & -3.388 \\
2010 & 1740.801 & -0.154 & -2.309 & $3.82 \mathrm{E}-06$ & 1.848 & -1.848 & 0.005746 & 3.388 & -2.002 \\
2011 & 1755.575 & 0.769 & 1.078 & $3.94 \mathrm{E}-06$ & 0.154 & -0.616 & 0.005789 & 3.542 & -3.079 \\
2012 & 1763.733 & 0.616 & -0.616 & $3.98 \mathrm{E}-06$ & 0.769 & -1.848 & 0.00569 & 3.849 & -3.388 \\
\hline
\end{tabular}

Table 9. Man-Kendall rank statistical table for $\mathrm{CO}_{2}$.

\begin{tabular}{cccc}
\hline YEARS & $\mathrm{CO}_{2}$ & $\mathrm{U}\left(\mathrm{t}_{\mathrm{i}}\right)$ & $\mathrm{U}^{\prime}(\mathrm{t})$ \\
\hline 2009 & 387.1489 & 1.694 & -1.078 \\
2010 & 381.1618 & 1.539 & -1.232 \\
2011 & 382.8326 & 0.769 & 1.078 \\
2012 & 386.8387 & 2.309 & 0.924 \\
2013 & 388.2413 & 1.386 & -1.078 \\
\hline
\end{tabular}




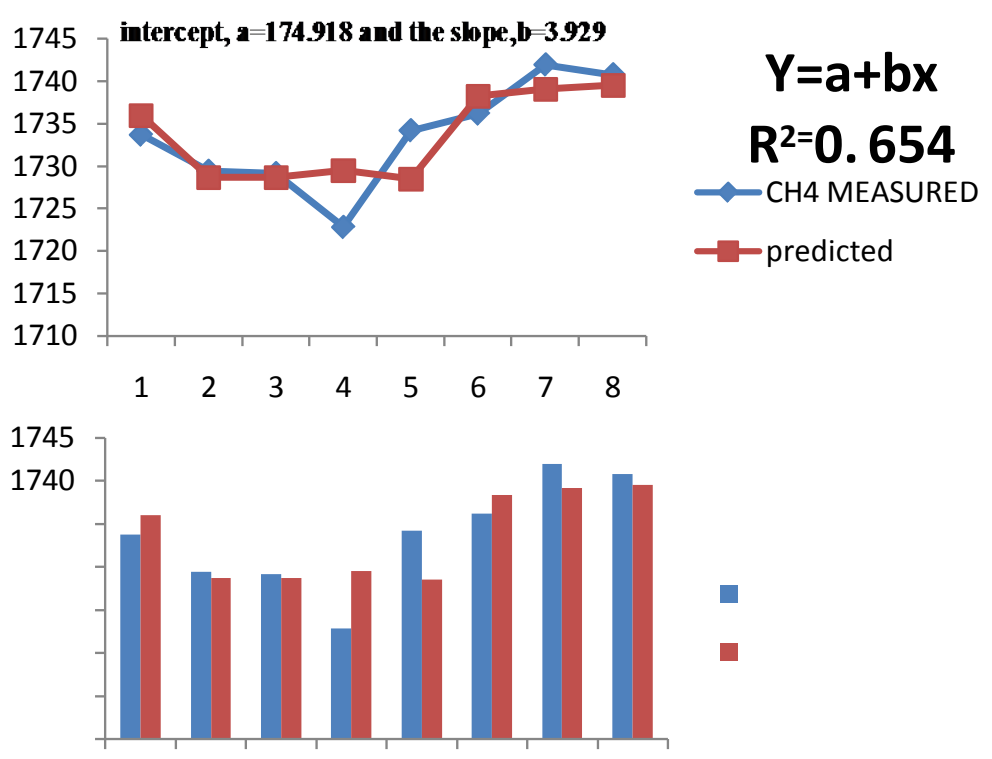

Figure 2. Graph of agreement between measured and predicted value of methane.

$$
Y=a+b X
$$

where,

$Y$ is the $\mathrm{CH}_{4}$ concentration,

$X$ is the wind speed,

$a=174.918$ is the intercept,

$b=3.929$, and the slope,

$R^{2}=0.654$ (significant at 1 percentile).

Also, the concentration of the variables were input into the regression equation and Methane $\left(\mathrm{CH}_{4}\right)$ with all the weather parameters show a weak significance in the statistical analysis with none of the parameters meeting the entry requirement for $\mathrm{NO}_{2}$ when analysed in the regression equation.

The regression analysis between the measured and predicted $\mathrm{O}_{3}$ (Figure 3) a relationship expressed as:

$$
Y=a+b X
$$

where,

$Y$ is the $\mathrm{O}_{3}$ concentration,

$X$ is the wind speed,

$a=0.006$ is the intercept,

$b=7.101 \mathrm{E}-005$, and the slope,

$R^{2}=0.810$ (significant at 1 percentile).

Figure 4(A)-(D) showed that the pollutants' trends in the Niger Delta are temporal but with high concentration during the dry season.

Figure 4(A)-(C), Figure 5(A) and Figure 5(B) respectively showed a non-linear trend in the mean annual concentration plots for $\mathrm{CH}_{4}, \mathrm{NO}_{2}, \mathrm{O}_{3}$ and $\mathrm{CO}_{2}$. While Figure $5(\mathrm{C})$ shows the mean annual concentrations of $\mathrm{NO}_{2}$ and average temperature. 

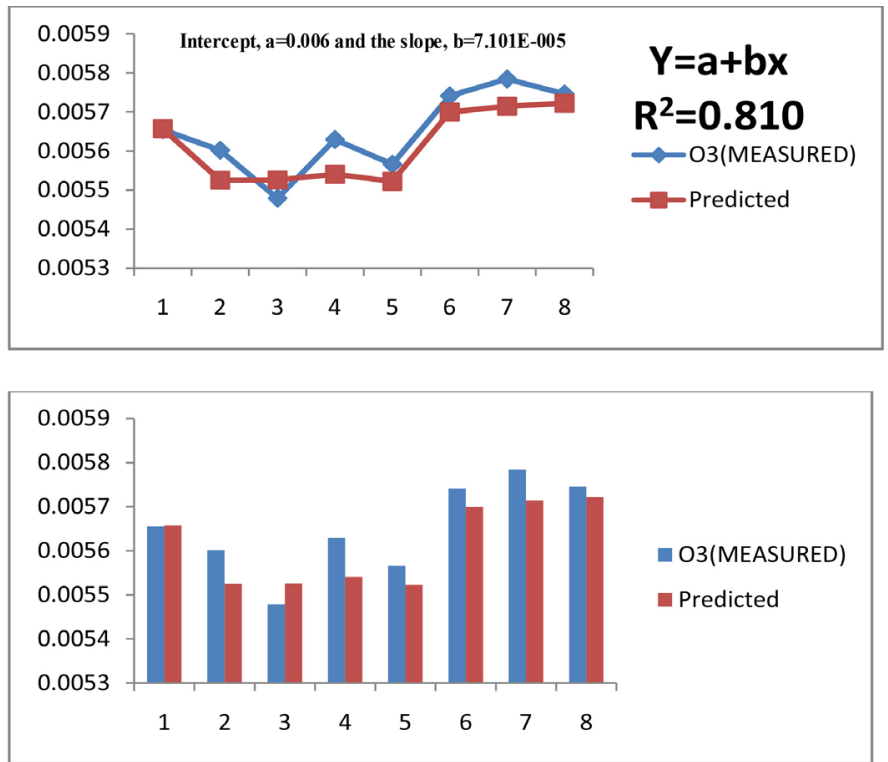

Figure 3. Graph of agreement between measured and predicted value of ozone.

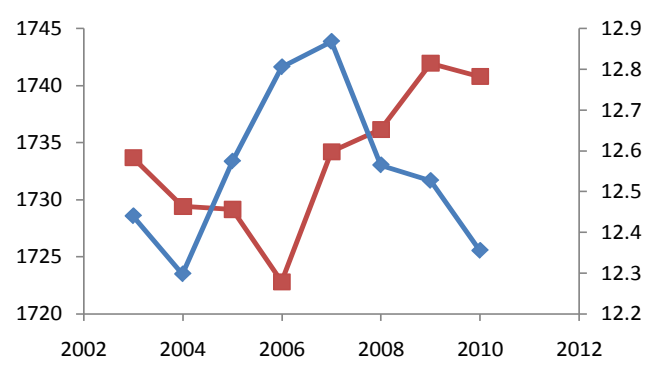

(A)

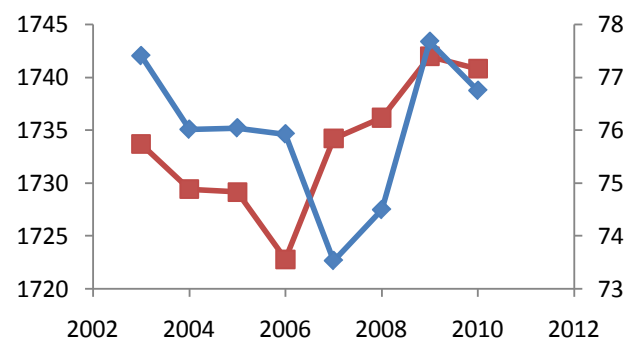

(a)

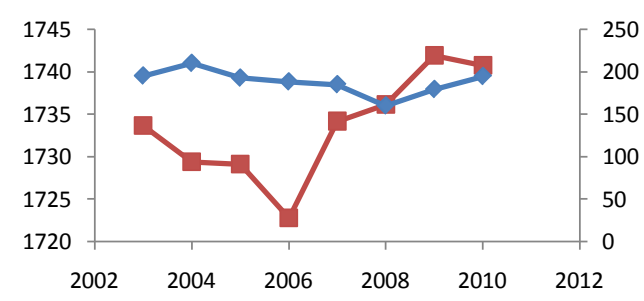

(c)

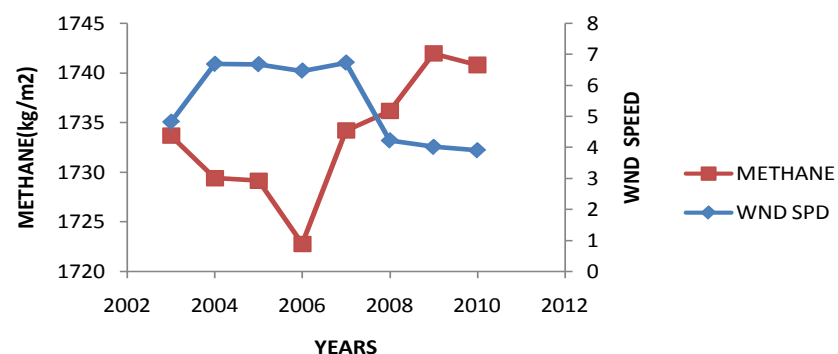

(B)

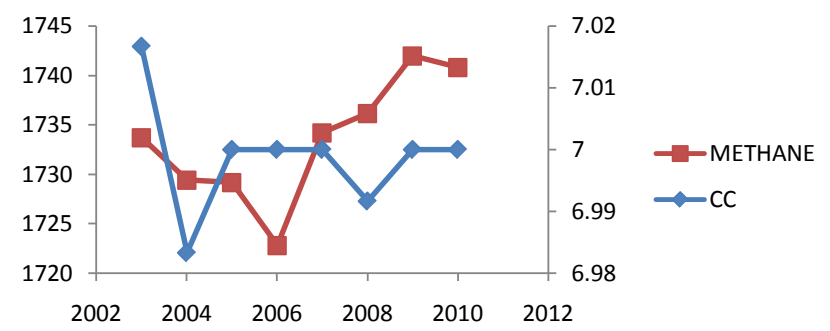

(b)

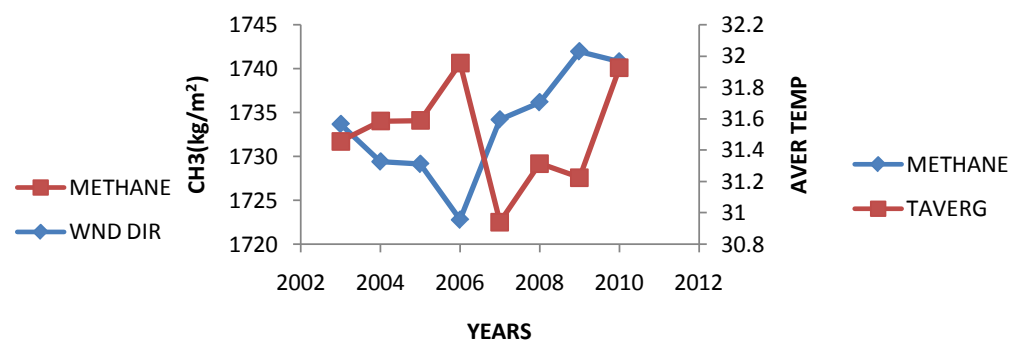

(d)

(C)

Figure 4. (A) Methane Correlation with Solar radiation; (B) Methane correlation with wind speed; (C) Methane concentration correlation with (a) Relative humidity, (b) cloud cover, (c) wind direction and (d) temperature. 


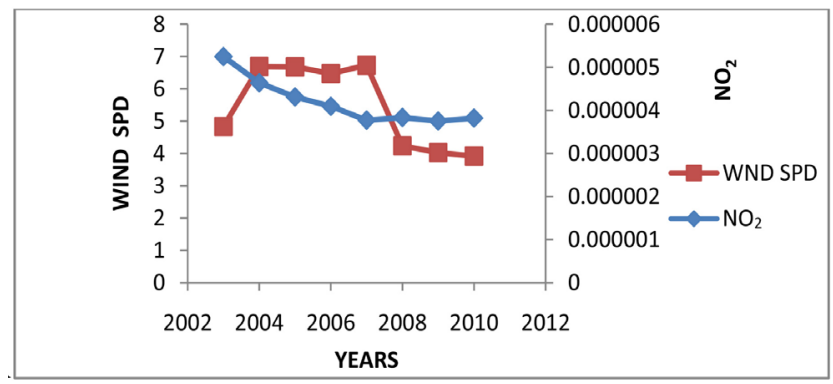

(a)

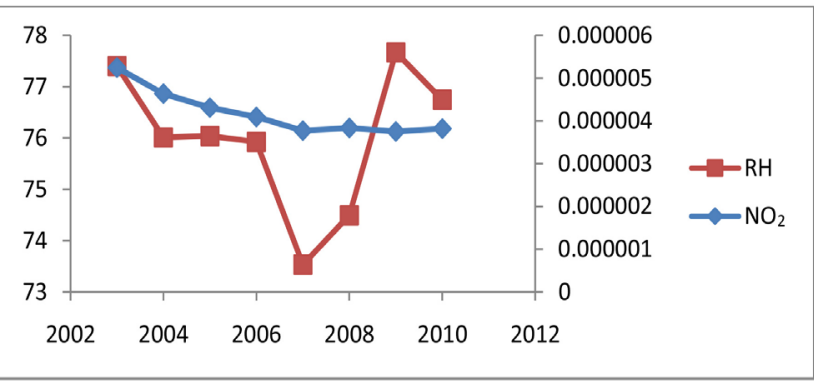

(b)

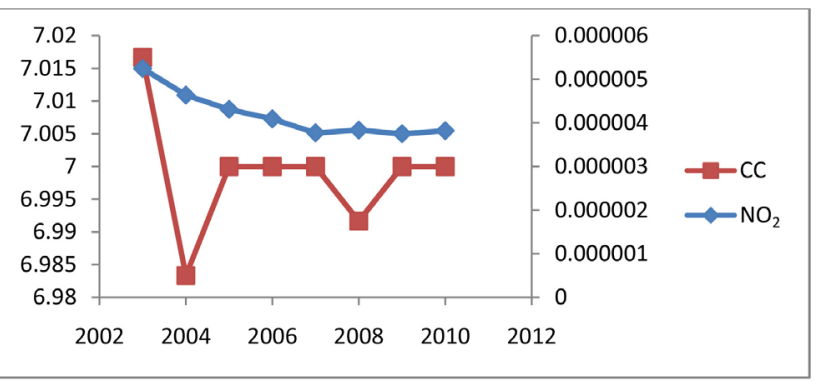

(c)

(A)

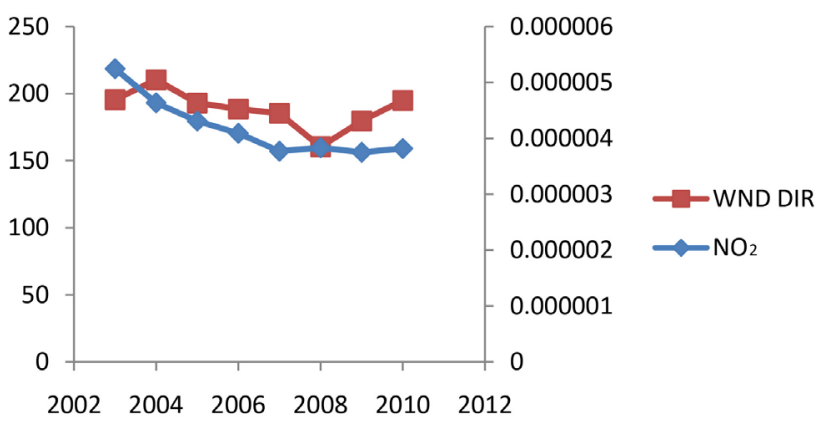

(a)

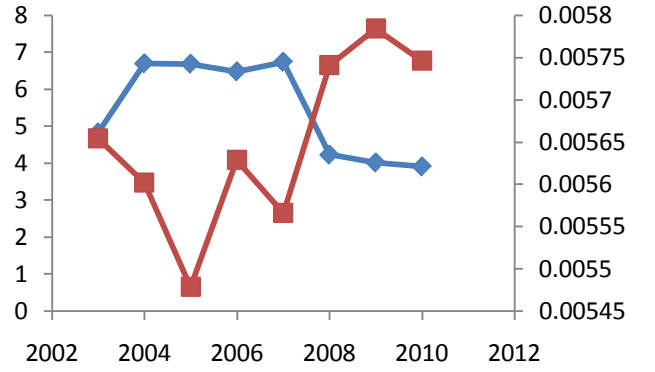

(b)

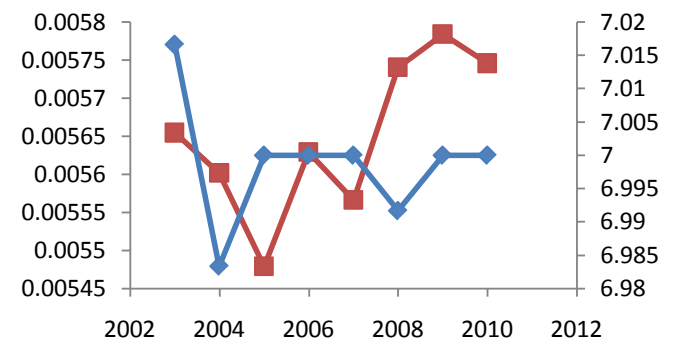

(d)

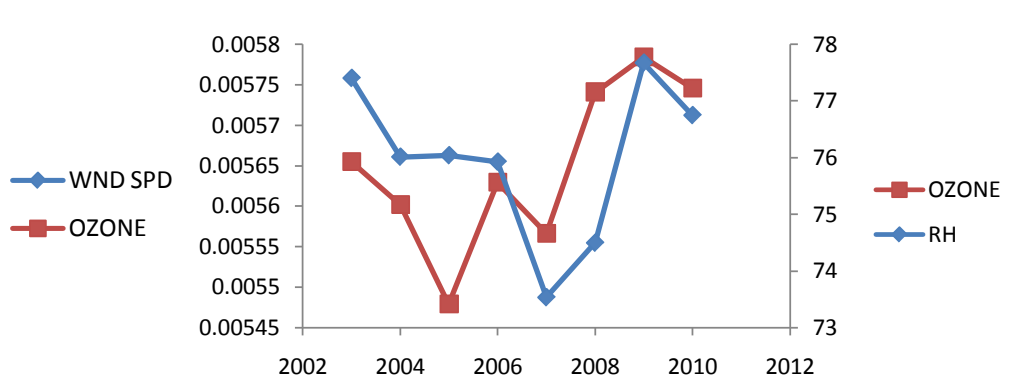

(c)

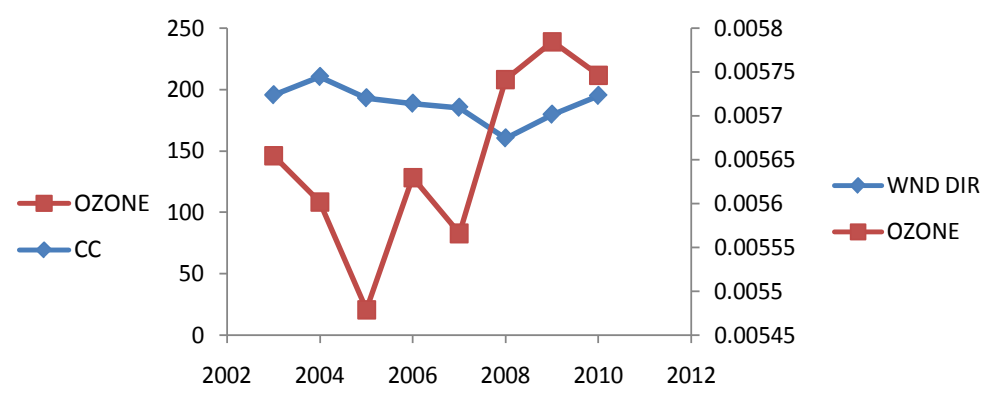

(e) 


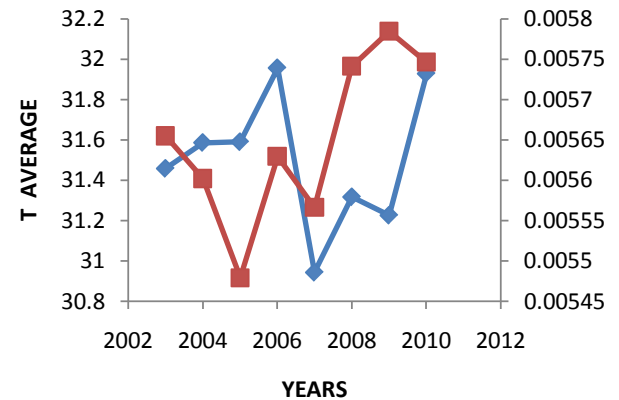

(f)

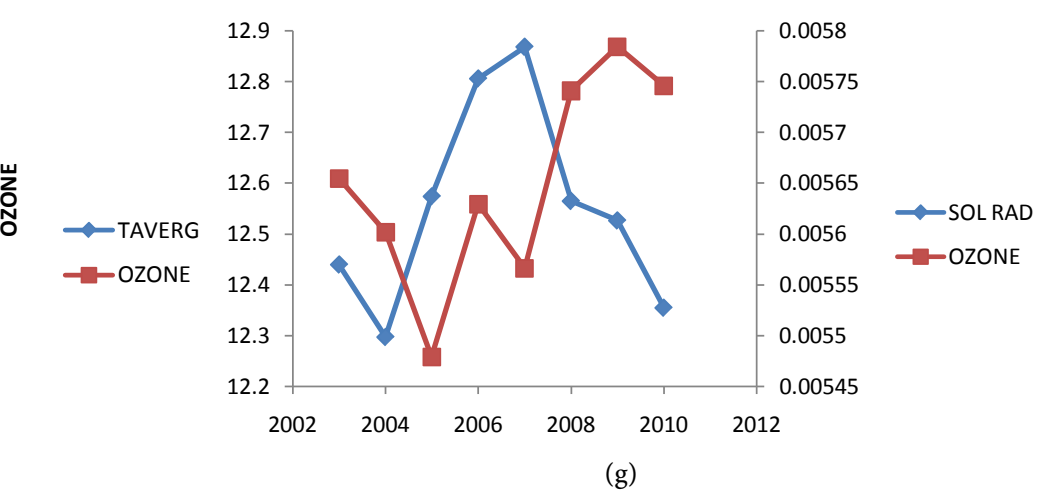

(B)

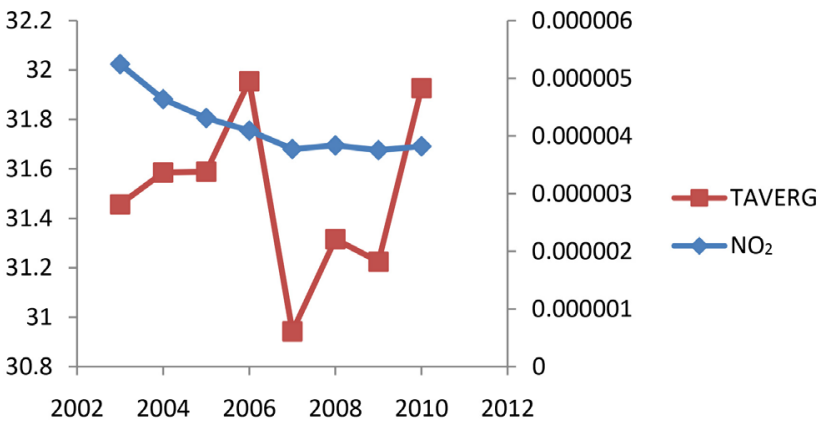

(C)

Figure 5. (A) $\mathrm{NO}_{2}$ concentration correlation with (a) wind speed; (b) relative humidity; (c) cloud cover; (B) Ozone concentration correlation with all the parameters; $(\mathrm{C}) \mathrm{NO}_{2}$ concentration correlation with wind direction and temperature.

The Mann-Kendal rank statistics showed that the standardization variables $\mathrm{U}^{\prime}\left(\mathrm{t}_{\mathrm{i}}\right)$ for all the pollutants between the period of studies (2003-2012) has a sequential fluctuating behaviour around a zero level and which confirms validity of the trends used and the homogeneity of the pollutants considered in the region Figures 6(A)-(D).

The $\mathrm{CH}_{4}, \mathrm{NO}_{2}$ and $\mathrm{O}_{3}$ concentrations are the dependent variables, while meteorological factors are the independent variables. In this study, because the statistical analysis of the relative humidity showed an insignificant value, it was therefore not imputed into the equation for $\mathrm{CH}_{4}$. It was only the wind speed that survived among the parameter utilized in this work because of its very high significance value in the statistical analysis. Also, the other parameters such as temperature, cloud cover and solar radiations were eliminated from the regression equation for $\mathrm{CH}_{4}$ because of their very weak significant values in the statistical analysis. For $\mathrm{NO}_{2}$, none of the parameters meet up with the entry requirement in the equation because all the other parameters showed a weak correlation with it $\left(\mathrm{NO}_{2}\right)$, hence the equation terminated when the regression analysis was carried out.

The remaining parameters considered in this work also showed weak relationship with tropospheric ozone except the wind speed which showed a very strong relationship with ozone. Hence, it was the only surviving parameter in the regression equation analysis. 


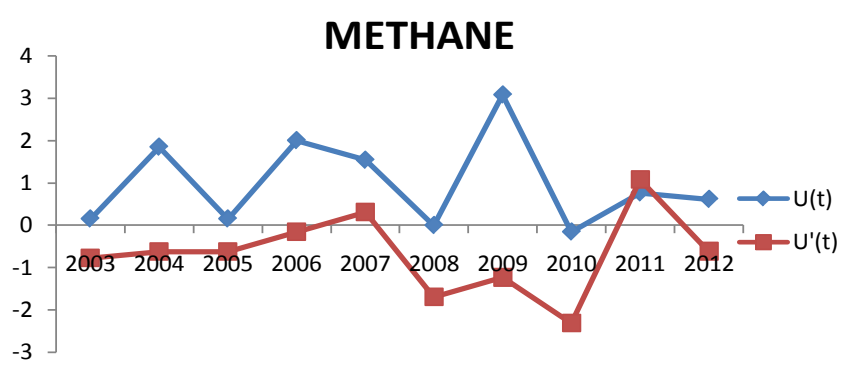

(A)

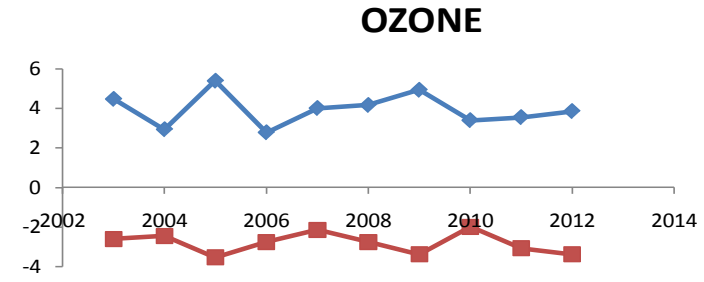

(C)

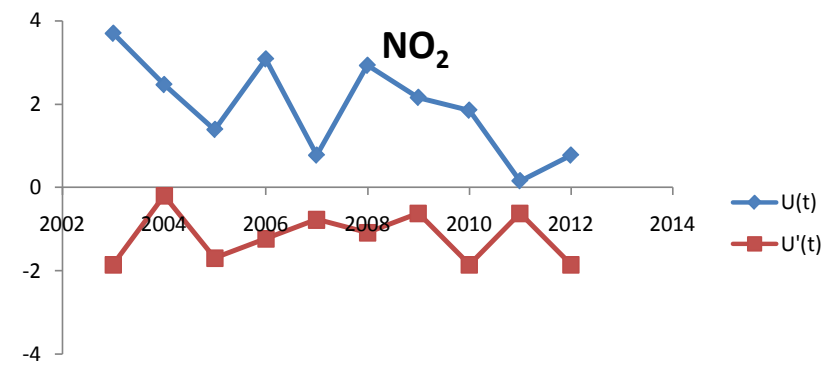

(B)

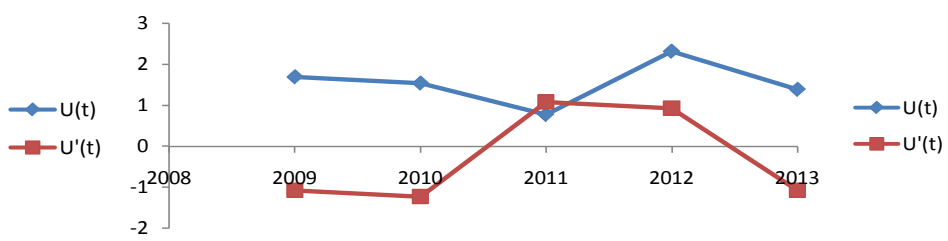

(D)

Figure 6. (A) Graph of Man-Kendall trend validation statistics for Methane; (B) Graph of Man-Kendall trend validation statistics for $\mathrm{NO}_{2}$; (C) Graph of Man-Kendall trend validation statistics for ozone; (D) Graph of Man-Kendal trend validation statistics for $\mathrm{CO}_{2}$.

There was a very strong correlation and a good coefficient of determination of about (81\%) between $\mathrm{O}_{3}$ concentration and the previous year's ozone concentration with the following parameters: wind speed, temperature, relative humidity, cloud cover, in which $19 \%$ is undetermined. In a similar way, there was also a strong dependence of $\mathrm{CH}_{4}$ concentration and the previous year's concentration on the following parameters: wind speed, temperature, relative humidity. The regression model in Equation (1) showed that $65 \%$ of $\mathrm{CH}_{4}$ has a very good dependence on these factors; where as $35 \%$ is undetermined. However, because of the weak dependence of $\mathrm{NO}_{2}$ concentration on these factors, it was not possible for it to be modelled. The value from the correlation table is very low $(0.213)$ for wind speed. This value cannot be modelled as the model will not survive the values below 0.5 . The coefficient of determination was not obtained and so the rate of dependence is generally indeterminate.

A Pearson correlation was carried out on the 10 years data set. $\mathrm{CH}_{4}, \mathrm{O}_{3}$ and $\mathrm{NO}_{2}$ monthly concentrations were correlated against monthly meteorological parameters (Table 2). This correlation was carried out to ascertain which of the atmospheric parameters were important in describing the behaviour of pollutants.

The Pearson correlation coefficient shows that solar radiation has a negative correlation with methane indicating that the increase in solar radiation causes a decrease in methane's concentration. This behaviour may be attributed to increase in heat flux which causes dry deposition and pollutant fall out.

Wind speed has a very strong negative correlation with methane concentration in Niger Delta (Figure 2 and Figure 3). This implies that the high decrease in speed of wind causes much increase in the production of methane. This is be- 
cause at low wind speed, the emitted pollutant (methane) tends to accumulate near the source area and disperses with an increasing wind speed due to higher ventilation.

Close observations reveals that solar radiation lowers the concentration of ozone in Niger Delta region as it shows negative correlation with ozone concentration. The concentration wind of ozone with speed shows a strong negative value. This implies that increase in wind speed decreases the accumulation of ozone as much speed of the wind tends to disperse the pollutants and decreases the concentrations due to higher ventilation. Relative humidity shows a moderate positive correlation with ozone concentration while cloud cover and temperature shows a very weak positive correlation with ozone. This implies that the increase in these parameters causes a slight increase in ozone concentration.

Figure 4(C) and Figure 5(C) showed that $\mathrm{CH}_{4}$ and $\mathrm{NO}_{2}$ concentration decreases with increasing temperature, while Ozone concentration is the opposite in which it increases as temperature also increases (Figure 5(B)). There is a very strong negative correlation between wind speed and the pollutant $\left(\mathrm{O}_{3}\right.$ and $\left.\mathrm{CH}_{4}\right)$ concentrations $\left(\mathrm{P}<0.01\right.$ for $\mathrm{O}_{3}$ and $\mathrm{CH}_{4}$ ) (Figure 4(B) and Figure 5(B)). This implies that wind speed, among all the meteorological parameters studied, has more influence on the variation of $\mathrm{O}_{3}, \mathrm{NO}_{2}$ and $\mathrm{CH}_{4}$ concentrations in the region of the Niger Delta, giving as high as $81 \%$ and $64 \%$ for $\mathrm{O}_{3}$ and $\mathrm{CH}_{4}$ respectively (Figure 2 and Figure 3), while all the parameters are of less significance with $\mathrm{NO}_{2}$ (Figure 5(B) and Figure 5(C)).

Wind speed, temperature, and solar radiation are effective meteorological variables in decreasing $\mathrm{CH}_{4}$ concentration. Solar radiation is also effective meteorological variable in decreasing $\mathrm{NO}_{2}$ concentration. Wind speed, solar radiation, wind direction, and minimum temperature are effective meteorological variable in decreasing $\mathrm{O}_{3}$, concentration. Whereas, maximum temperature, relative humidity and cloud cover promotes $\mathrm{O}_{3}$ concentration although it is only the effect of wind speed that is strongly significant $(\mathrm{P}<0.01)[12]$.

\section{Conclusion}

The spatial and temporal distribution of daily $\mathrm{CH}_{4}$ (Methane), $\mathrm{NO}_{2}$ (nitrogen dioxides) and $\mathrm{O}_{3}$ (ozone) concentration in the Niger Delta region was observed depend on the variations in atmospheric parameters. A very strong negative correlation was obtained between wind speed and both the $\mathrm{CH}_{4}$ and $\mathrm{O}_{3}$ pollutants respectively, and a moderate correlation was obtained between the wind speed and $\mathrm{NO}_{2}$. This implies that amongst the atmospheric parameters considered in this study for the region of the Niger Delta in Nigeria, wind speed has much influence on the variation of both $\mathrm{CH}_{4}$ and $\mathrm{O}_{3}$ concentrations, but with a little influence on the $\mathrm{NO}_{2}$ concentrations.

\section{Conflicts of Interest}

The authors declare no conflicts of interest regarding the publication of this paper. 


\section{References}

[1] Odigure, J.O. (1998) Safety Loss and Pollution Control in Chemical Processes, Industries, Jodigs and Association, Minna, Nigeria. 89-93.

[2] Anderson, I. (2005) Niger River Basin: A Vision for Sustainable Development. The World Bank, $131 \mathrm{p}$

[3] Oyekunle, L.O. (1999) Effect of Gas Flaring in Niger-Delta Area. NSChE Proceedings, Port-Harcourt, 13 p.

[4] Ede, P.N. and Edokpa, D.O. (2015) Regional Air Quality of the Nigeria's Niger Delta. Open Journal of Air Pollution, 4, 7-15. https://doi.org/10.4236/ojap.2015.41002

[5] Alakpodia, I.J. (1980) The Effect of Gas Flaring on the Microclimate and Adjacent Vegetation in Isoko Area. Unpublished M.Sc. Thesis, University of Lagos, Nigeria.

[6] Anochie, U.C. and Onyinye, O.M. (2015) Evaluation of Some Oil Companies in the Niger Delta Region of Nigeria: An Environmental Impact Approach. International Journal of Environmental and Pollution Research, 3, 13-31.

[7] Ngele, S.O., Eboatu, A.N. and Onwu, F.K. (2012) Preliminary Study of the Influence of Some Meteorological Parameters on the Concentration of CO in South Eastern Part of Nigeria. Chemical Science Transactions, 1, 702-708. https://doi.org/10.7598/cst2012.4395

[8] Faboya, O. (1997) Industrial Pollution and the Waste Management. In: Osuntokun, A., Ed., Dimensions of Environmental Problems in Nigeria, Ibadan Davidson Press, Nigeria, 26-35

[9] Iyoha, M.A. (2009) The Environmental Effects of Oil Industry Activities on the Nigerian Economy: A Theoretical Analysis. A Paper Presented at National Conference in the Management of Nigeria's Petroleum Resources, Organised by the Department of Economics, Delta State University.

[10] Ojo, O.O.S. and Awokola, O.S. (2012) Investigation of Air Pollution from Automobiles at Intersections on Some Selected Major Roads in Ogbomoso, South Western, Nigeria. IOSR Journal of Mechanical and Civil Engineering, 1, 31-35. https://doi.org/10.9790/1684-0143135

[11] Weli, V.E. (2014) Spatial and Seasonal Influence on Meteorological Parameters on the concentration of Suspended Particulate Matter in an industrial city of Port Harcourt, Nigeria. Developing Country Studies, 4, 112-121.

[12] Latini, G., Cocci Grifoni, R. and Passerini, G. (2002) Influence of Meteorological Parameters on Urban and Suburban Air Pollution. WIT Press, Ashurst Lodge, Southampton, SO40 7AA, UK, 753-764 